\title{
PHYSIOLOGICAL STUDIES ON GERMINATION AND GROWTH OF OCHNA SHRUB. B- EFFECT OF IRRIGATION INTERVALS ON GROWTH AND QUALITY OF Ochna serrulata (HOCHST.) SEEDLINGS GROWN IN DIFFERENT MEDIA.
}

(Received: 28.2.2021)

\author{
By \\ S. M. Shahin and A. W. Sayed * \\ Botanical Gardens and *Ornamental Plants and Landscape Gardening Research Department \\ Horticulture Research Institute, Agriculture Research Center, Giza, Egypt.
}

\begin{abstract}
A pot experiment was conducted under saran at the nursery of Al-Zohriya Garden, Hort. Res. Inst., ARC, Giza, Egypt during 2018 and 2019 seasons to study the effect of following growing media: the pure sand $(\mathrm{S}), \mathrm{S}+$ clay at either $(3: 1, \mathrm{v} / \mathrm{v})$ or $(1: 1, \mathrm{v} / \mathrm{v})$ and $\mathrm{S}+$ farmyard manure $(\mathrm{FYM})$ compost at either $(3: 1, \mathrm{v} / \mathrm{v})$ or $(1: 1, \mathrm{v} / \mathrm{v})$, irrigation intervals ( once every 1,2 and 3 days) and their interactions on growth and quality of Mickey Mouse plant (Ochna serrulata Hochst.) transplants of 10-month-old during the rearing period in the nursery.

It was found that amending the sand with either clay or FYM compost at any ratio in these studies significantly improved all vegetative and root growth parameters, with the superiority of the mixture, sand + FYM compost $(3: 1 \mathrm{v} / \mathrm{v})$, which gave the highest means of plant height, No. leaves/plant, root length and fresh and dry weights of shoots and roots compared to all the other media in both seasons. On the other hand, shortening irrigation period from 3 to either 2 or 1 days significantly hastened growth with the prevalence of 2 days irrigation interval that attained means higher, to some extent, than daily irrigation in most growth characters in the two seasons. So, the best vegetative and root growth criteria of Ochna plant were obtained from planting in the mixture of sand + FYM compost $(3: 1, \mathrm{v} / \mathrm{v})$ with irrigation every 2 days. A similar trend to that of vegetative and root growth results was also occurred concerning chlorophyll a, b, carotenoids and total soluble sugars concentrations in the leaves .

From such gains, it can be proposed to culture the small transplants of Mickey Mouse bush (Ochna serrulata) under shade in sand + formyard manure compost mixture $(3: 1, \mathrm{v} / \mathrm{v})$ and watering them once every two days to speed growth of this slow-growing shrub during the incubation period in the nursery .
\end{abstract}

Key words: Mickey Mouse bush (Ochna serrulata), FYM, irrigation interval, vegetative and root growth, chemical constituents.

\section{INTRODUCTION}

Mickey Mouse plant, or Bird's Eye bush (Ochna serrulata (Hochst.) Walp.), a showy bush of the family Ochnaceae that is native to the coast of Southern Africa. It is a slowgrowing semi-evergreen small shrub, up to $2.5 \mathrm{~m}$ height with a slender dark brown smooth-barked stem and elliptical glossy green leaves with fine toothed wavy margins. It has beautiful yellow fragrant flowers forming at branch tips in spring, and very attractive fruits that are shiny black and berry-like, suspended below bright-red sepals in a way that resembles the face of Mickey Mouse (Huxley et al., 1992). This plant can tolerate wet and heavy soils, and may tolerate dry conditions when planted in the shade. It also tolerates wind and seaside conditions and takes well to regular hedging and pruning, making it the proper option for formal or informal small hedge. It can also be used as a feature plant, or in the mixed border. It looks good and does well growing amongst rocks, as a container plant and has a great potential as a bonsai one. It is propagated by seeds and cuttings (Hattatt, 2001).

Ochna could be used in folk medicine, for treatment of some ailments, such as asthma, dysentery, epilepsy, gastric disorders, lumbago, menstrual complaints, ulcers, as an abortifacient and as an antidote against snake bites (Bandi et al., 2012). Up to now, about 111 constituents, 
including flavonoids, anthranoids, triterpenes, steroids, fatty acids and some others identified in the oil (the seeds contain about $31 \%$ oil) by Makhafola and Eloff (2012), Voegele (2013) and Fidelis et al. (2014).

The growing medium is one of the main factors affecting plant production. Thus, preparing a good medium suitable for the slowgrowing plants such as Ochna bush may help in improving their growth and flowering. In this regard, Saadawy et al. (2005) found that using broad bean compost medium produced the tallest Peperomia plants, the highest leaf and branch number/plant and the heaviest shoot dry weight and root fresh weight. Such medium also increased Syngonium roots to maximum value. The tallest plants, the highest No. leaves of Schefflera plant as well as the heaviest fresh and dry weights roots of both Schefflera and Syngonium were achieved by planting them in bagasse compost medium. The highest $\mathrm{K} \%$ in the three mentioned plants was found in plants grown in broad bean straw medium, whereas bagasse compost medium increased the contents of total chlorophylls, N, P and carbohydrates to highest concentrations in the three studied plants. Similar observations were also obtained by Abdel Fattah et al. (2008) on Schefflera actinophylla, El-Sayed et al. (2013) on Euonymus japonicus, El-Quasni et al. (2014) on Magnolia grandiflora, Sarhan et al. (2016) on Moringa oleifera and Meshaal et al. (2018) on Russelia equisetiformis.

In addition, minimizing plant water requirements to the least level without plant injury and physiological disorders are very important, especially under the present climatic changes accompanied with water deficit. In this concern, Abdel- Moneim et al. (2018) declared that prolonging irrigation interval from one to two weeks resulted in the highest number of leaves and flowers, flower diameter, flower fresh and dry weights, as well as total chlorophyll, $\mathrm{P}$ and $\mathrm{K}$ concentrations in Euphorbia milii var. longifolia plants. SSimilar results were reported by Henson et al. (2006) on Catharanthus roseus, Rudbeckia hirta, Senecia cineraria,Tagetes erecta, T. patula, Salvia farinacea and Petunia hybrida, Tahir et al. (2007) on canola, Ibrahim et al. (2010) on Helichrysum bracteatum, ElMekawy (2013) on Achillea santolina, Mohamed et al. (2014) on Curcuma aromatica and $C$. domestica, El- Leithy et al. (2018 b) on rosemary, Akhtar (2019) on Calendula officinalis and Dianthus berbatus, Ahmad et al. (2020) on roselle and Do Bomfim et al. (2020) on Ananas comosus plants.

The effect of interaction between irrigation regime and medium ingredients on ornamentals was studied as well by Shahin et al. (2007) who revealed that watering Agave americana cv. Marginata transplants grown in sand + loam $(10 \%)+$ chicken manure $(10 \%)$ mixture and irrigated with $150 \mathrm{ml}$ water/clay pot $(15 \mathrm{~cm}$ diameter) scored the best vegetative and root growth, highest number and quality of new suckers and greatest concentrations of chlorophyll a, b and carotenoids in the leaves, as well as the contents of total carbohydrates, N, P and $\mathrm{K}$ in the leaves and roots. Parallel responses were also discovered by Moore and Broschat (2001) on areca palm, crossandra, pentas and philodendron plants, Shahin et al. (2009) on tuberose, Saadawy et al. (2011) on Ficus "Hawaii", Mazher et al. (2012) on Amaranthus tricolor, Nofal et al. (2014) on Hymenocallis speciosa and Said (2016) on Duranta erecta var. Variegata.

This trialaimed to determine the most appropriate medium and irrigation interval necessary for good and healthy growth of the slow-growing Mickey Mouse shrub during the rearing period in the nursery.

\section{MATERIALS AND METHODS}

A pot experiment was carried out under saran at the nursery of Al-Zohriya Garden, Hort. Res. Inst., ARC, Giza, Egypt throughout the two successive seasons of 2018 and 2019 to find out the best growing mixture and irrigation interval needed for promoting growth of Ochna bush to be reliable for the quick marketing.

Ten-month-old uniform seedlings of Ochna serrulata (Hochst.) shrub were carefully transplanted on $15^{\text {th }}$ April in both seasons in 20 $\mathrm{cm}$ diameter plastic pots (one seedling/pot). The pots were filled with one of the following mixtures: pure sand (S) as a control, $\mathrm{S}+$ clay $(3: 1, \mathrm{v} / \mathrm{v}), \mathrm{S}+$ clay $(1: 1, \mathrm{v} / \mathrm{v}), \mathrm{S}+\mathrm{FYM}$ compost $(3: 1, v / v)$ and $S+F Y M$ compost $(1: 1, v / v)$ up to $1 \mathrm{~cm}$ past the pot rim. Physical and chemical analyses of the sand and clay used in the two seasons were determined and illustrted in Table (a), while those of farm yard manure (FYM) compost are listed in Table (b). 
Table (a): Some physical and chemical analyses of the sand and clay used in the two experimental season.

\begin{tabular}{|c|c|c|c|c|c|c|c|c|c|c|c|c|c|c|}
\hline 宫 & \multicolumn{4}{|c|}{ Particle size distribution (\%) } & S.P & $\begin{array}{c}\text { E.C. } \\
(\mathrm{dS} / \mathrm{m})\end{array}$ & pH & \multicolumn{4}{|c|}{ Cations (meq/l) } & \multicolumn{3}{|c|}{ Anions (meq/l) } \\
\hline Clay & 7.34 & 22.25 & 30.57 & 39.84 & 55.33 & 2.26 & 8.11 & 7.82 & 2.12 & 15.33 & 0.82 & 6.61 & 8.23 & 11.25 \\
\hline
\end{tabular}

Table (b): The physical and chemical analyses of the FYM compost in both seasons.

\begin{tabular}{|c|c|c|c|c|c|c|c|c|c|c|c|c|c|}
\hline \multirow{2}{*}{$\underset{(\%)}{\text { O.M. }}$} & \multirow{2}{*}{$\begin{array}{c}\text { O.C. } \\
(\%)\end{array}$} & \multirow{2}{*}{$\begin{array}{l}\mathrm{C} / \mathrm{N} \\
\text { ratio }\end{array}$} & \multirow{2}{*}{$\mathbf{p H}$} & \multirow{2}{*}{$\begin{array}{c}\text { E.C. } \\
(\mathrm{dS} / \mathrm{m})\end{array}$} & \multicolumn{5}{|c|}{ Macroelements (\%) } & \multicolumn{4}{|c|}{ Microelements (ppm) } \\
\hline & & & & & $\mathbf{N}$ & $\mathbf{P}$ & $\mathbf{K}$ & $\mathbf{C a}$ & Mg & $\mathbf{Z n}$ & $\mathbf{F e}$ & Mn & $\mathbf{C u}$ \\
\hline 25.80 & 23.28 & 12.58 & 7.78 & 3.57 & 1.85 & 0.71 & 2.29 & 0.25 & 0.79 & 20.10 & 1620.0 & 330.0 & 54.0 \\
\hline
\end{tabular}

The seedlings were regularly irrigated once every three days with $300 \mathrm{ml}$ of tap water/pot till $1^{\text {st }}$ May, when they were watered afterwards once every 1,2 or 3 days till end of the experiment on mid of October. The used five media were combined factorially with the three irrigation intervals to create fifteen interaction treatments.

A factorial experiment in a complete randomized design was conducted in the two seasons, with 3 replicates, each containing 5 plants (Mead et al., 1993). All plants under the various treatments received the usual agricultural practices whenever required. At the end of each season, the data were recorded as follows: plant height $(\mathrm{cm})$, number of leaves/plant, the longest root length $(\mathrm{cm})$, as well as the top growth and roots fresh and dry weights $(\mathrm{g})$. In fresh leaf samples taken from the middle part of the plant, the contents of photosynthetic pigments (chlorophyll a, b and carotenoids, mg/g f. w.) and the percent of total soluble sugars were determined using the methods described by Sumanta et al. (2014) and Dubois et al. (1956), respectively.

The data were statistically analyzed using the Assistant Software Program (Silva and Azevedo, 2016), followed by Duncan's New Multiple Range t-Test (Steel and Torrie, 1980) to compare the means of the various treatments.

\section{RESULTS AND DISCUSSION}

\subsection{Effect of irrigation interval, media and their interactions on}

\subsubsection{Vegetative and root growth parameters}

It is obvious from data averaged in Tables (1, 2 and 3 ) that plants raised in pure sand medium and watered once every 3 days were dead giving zero values in all vegetative and root growth characters measured in both seasons showing its low tolerance for long irrigation interval under conditions of this study. However, amending the sand with either clay or farmyard manure compost at any portion significantly improved vegetative and root growth traits with the superiority of sand + FYM compost $(3: 1, \mathrm{v} / \mathrm{v})$ medium, which gave the tallest plant, highest number of leaves, longest roots and heaviest fresh and dry weights of shoots and roots compared to the other growing media in the two seasons. This may be attributed to the high manure values of the FYM compost, which supplies the plants with the different nutrients needed for quality and healthy growth (Abdel-Fattah et al., 2008). Moreover, the well composted FYM may improve structure and texture of the growing medium, electrical conductivity, $\mathrm{pH}$, organic matter content, cation exchange capacity and fertility (Drechsel and Reck, 1998), besides, rising the water holding capacity of the medium, consequently water uptake by plants (Gonzalez and Cooperband, 2003).

On the other side, growing plants under irrigation regime at 2 or 1 days significantly speed up growth with the superiority of 2 days interval treatment, which was better than 1 day interval in most growth characters as compared with 3 day interval in both seasons. Thus, the best vegetative and root growth attributes were gained from planting Ochna serrulata seedling in $\mathrm{S}+\mathrm{FYM}$ compost $(3: 1 \mathrm{v} / \mathrm{v})$ medium and irrigation once every 2 days, as this combined treatment attained, in general, the utmost high means over all the other combinations in both seasons. This may be due to the impact of FYM in improving structure and texture of the growing mixture, increasing its cation exchange capacity and fertility with enhancing its water holding capacity, consequently water uptake by plants and the proper irrigation interval which may save enough water necessary for promoting 
Table (1): Effect of irrigation intervals, growing media and their interaction on plant height, No. leaves/plant and root length of Ochna serrulata seedlings during 2018 and 2019 seasons.

\begin{tabular}{|c|c|c|c|c|c|c|c|c|c|c|c|c|}
\hline \multirow{2}{*}{\begin{tabular}{|cc} 
Irrigation interval \\
Media
\end{tabular}} & \multicolumn{4}{|c|}{ Plant height $(\mathrm{cm})$} & \multicolumn{4}{|c|}{ No. leaves / plant } & \multicolumn{4}{|c|}{ Root length $(\mathrm{cm})$} \\
\hline & 3 & 2 & 1 & Mean & 3 & 2 & 1 & Mean & 3 & 2 & 1 & Mean \\
\hline & \multicolumn{12}{|c|}{ First season: 2018} \\
\hline \begin{tabular}{|l|} 
Pure sand (S) \\
\end{tabular} & $0.00 \mathrm{i}$ & $21.33 \mathrm{~h}$ & $24.30 \mathrm{gh}$ & $15.21 E$ & $0.00 \mathrm{k}$ & $24.67 j$ & $31.00 \mathrm{i}$ & 18.46D & $0.00 \mathrm{~g}$ & $16.97 \mathrm{f}$ & $18.27 \mathrm{f}$ & $11.74 \mathrm{C}$ \\
\hline $\mathrm{S}+\operatorname{clay}(3: 1, \mathrm{v} / \mathrm{v})$ & $31.47 \mathrm{de}$ & $37.00 \mathrm{c}$ & $44.67 \mathrm{ab}$ & 37.71B & $36.33 \mathrm{~h}$ & $50.33 c$ & $58.67 \mathrm{~b}$ & 48.44B & $23.40 \mathrm{e}$ & $29.80 \mathrm{a}-\mathrm{c}$ & $27.77 \mathrm{~cd}$ & 26.99B \\
\hline $\mathrm{S}+$ clay $(1: 1, \mathrm{v} / \mathrm{v})$ & 32.00de & $37.97 \mathrm{c}$ & $32.73 d$ & $34.23 \mathrm{C}$ & $43.67 \mathrm{ef}$ & $52.33 c$ & $46.33 \mathrm{de}$ & 47.44B & $24.07 \mathrm{e}$ & $30.63 \mathrm{ab}$ & $27.43 \mathrm{~cd}$ & 27.38B \\
\hline S+ FYM compost $(3: 1, \mathrm{v} / \mathrm{v})$ & $33.90 \mathrm{~d}$ & $46.33 \mathrm{a}$ & $41.70 \mathrm{~b}$ & 40.64A & $49.67 \mathrm{~cd}$ & $76.00 \mathrm{a}$ & $52.00 \mathrm{c}$ & $59.22 \mathrm{~A}$ & $28.20 \mathrm{~b}-\mathrm{d}$ & $31.83 \mathrm{a}$ & $28.63 \mathrm{~b}-\mathrm{d}$ & 29.56A \\
\hline S+ FYM compost $(1: 1, \mathrm{v} / \mathrm{v})$ & $26.13 \mathrm{~h}$ & $29.00 \mathrm{ef}$ & $28.07 \mathrm{f}$ & 27.73D & $39.67 \mathrm{gh}$ & $44.33 \mathrm{ef}$ & $40.67 \mathrm{fg}$ & $41.46 \mathrm{C}$ & $24.40 \mathrm{e}$ & $27.93 b-d$ & $25.90 \mathrm{de}$ & 26.08B \\
\hline \multirow[t]{2}{*}{ Mean } & $24.70 B$ & 34.33A & 34.29A & & 33.87C & 49.53A & 45.73B & & $20.01 C$ & $27.43 \mathrm{~A}$ & $25.60 B$ & \\
\hline & \multicolumn{12}{|c|}{ Second season: 2019} \\
\hline \begin{tabular}{|l|} 
Pure sand (S) \\
\end{tabular} & $0.00 \mathrm{i}$ & $21.40 \mathrm{~h}$ & $26.97 \mathrm{~g}$ & 16.12D & $0.00 \mathrm{~h}$ & $40.67 \mathrm{~g}$ & $68.00 \mathrm{e}$ & $36.22 \mathrm{E}$ & $0.00 \mathrm{~h}$ & $18.53 \mathrm{~g}$ & $24.97 \mathrm{f}$ & $14.50 \mathrm{D}$ \\
\hline$S+\operatorname{clay}(3: 1, v / v)$ & $37.73 \mathrm{e}$ & $41.77 \mathrm{~cd}$ & $44.03 \mathrm{~cd}$ & 41.18B & $58.33 \mathrm{f}$ & $77.33 c$ & $82.67 \mathrm{~b}$ & 72.78C & $29.87 \mathrm{c}-\mathrm{e}$ & $31.33 \mathrm{~b}-\mathrm{d}$ & $31.37 \mathrm{~b}-\mathrm{d}$ & 30.86BC \\
\hline$S+$ clay $(1: 1, \mathrm{v} / \mathrm{v})$ & 40.60de & 43.30cd & $41.33 \mathrm{~cd}$ & 41.71B & $61.00 \mathrm{f}$ & $89.00 \mathrm{a}$ & $78.33 \mathrm{c}$ & 76.11B & $29.90 \mathrm{c}-\mathrm{e}$ & $32.77 \mathrm{ab}$ & $30.77 \mathrm{~b}-\mathrm{d}$ & 31.14B \\
\hline S+ FYM compost $(3: 1, \mathrm{v} / \mathrm{v})$ & $44.40 \mathrm{c}$ & $58.73 \mathrm{a}$ & $55.13 \mathrm{~b}$ & 52.76A & $71.67 \mathrm{~d}$ & $90.67 \mathrm{a}$ & $81.00 \mathrm{bc}$ & $81.11 \mathrm{~A}$ & $34.83 \mathrm{a}$ & $34.27 \mathrm{a}$ & $32.47 \mathrm{a}-\mathrm{c}$ & 33.86A \\
\hline S+ FYM compost $(1: 1, \mathrm{v} / \mathrm{v})$ & $31.10 \mathrm{f}$ & $33.33 \mathrm{f}$ & $30.20 \mathrm{f}$ & $31.54 \mathrm{C}$ & $57.67 \mathrm{f}$ & $73.33 d$ & $72.00 \mathrm{~d}$ & $67.67 \mathrm{D}$ & $27.80 \mathrm{e}$ & $31.27 \mathrm{~b}-\mathrm{d}$ & $29.53 \mathrm{de}$ & $29.53 \mathrm{C}$ \\
\hline Mean & 30.77B & 39.71A & 39.53A & & $49.73 \mathrm{C}$ & $74.20 \mathrm{~B}$ & $76.40 \mathrm{~A}$ & & $24.48 B$ & $29.63 \mathrm{~A}$ & $29.82 A$ & \\
\hline
\end{tabular}

*Means within column or row having the same letters are not significantly different according to Duncan's New Multiple Range t-Test at $5 \%$ level.

Table (2): Effect of irrigation intervals, growing media and their interaction on top growth fresh and dry weights of Ochna serrulata seedlings during 2018 and 2019 seasons.

\begin{tabular}{|c|c|c|c|c|c|c|c|c|}
\hline \multirow[t]{2}{*}{ Irrigation interval ( day) } & \multicolumn{4}{|c|}{ Top growth f. w.(g)/plant } & \multicolumn{4}{|c|}{ Top growth d. w.(g)/plant } \\
\hline & 3 & 2 & 1 & Mean & 3 & 2 & 1 & Mean \\
\hline & \multicolumn{8}{|c|}{ First season: 2018} \\
\hline Pure sand (S) & $0.00 \mathrm{~h}$ & $3.02 \mathrm{~g}$ & $3.50 \mathrm{fg}$ & 2.17D & $0.00 \mathrm{k}$ & $1.15 \mathrm{j}$ & $1.91 \mathrm{i}$ & $1.02 D$ \\
\hline $\mathrm{S}+\operatorname{clay}(3: 1, \mathrm{v} / \mathrm{v})$ & $4.63 \mathrm{e}$ & $6.98 \mathrm{c}$ & $7.57 b c$ & $6.40 \mathrm{~B}$ & $2.34 \mathrm{~g}-\mathrm{i}$ & $2.53 \mathrm{f}-\mathrm{h}$ & $4.03 \mathrm{~cd}$ & $2.97 \mathrm{C}$ \\
\hline $\mathrm{S}+$ clay $(1: 1, \mathrm{v} / \mathrm{v})$ & $4.66 \mathrm{e}$ & $7.89 \mathrm{~b}$ & $7.04 \mathrm{c}$ & $6.53 B$ & $2.84 \mathrm{fg}$ & $4.20 \mathrm{bc}$ & $3.61 \mathrm{de}$ & 3.55B \\
\hline S+ FYM compost $(3: 1, v / v)$ & $5.12 \mathrm{de}$ & $9.50 \mathrm{a}$ & $8.85 a$ & $7.83 \mathrm{~A}$ & $3.07 \mathrm{ef}$ & $4.91 \mathrm{a}$ & $4.71 \mathrm{ab}$ & $4.23 \mathrm{~A}$ \\
\hline S+ FYM compost $(1: 1, v / v)$ & $3.91 \mathrm{f}$ & $5.76 \mathrm{~d}$ & $5.49 \mathrm{~d}$ & $5.05 \mathrm{C}$ & $2.05 \mathrm{hi}$ & $3.59 \mathrm{de}$ & $2.33 g-i$ & $2.65 \mathrm{C}$ \\
\hline \multirow[t]{2}{*}{ Mean } & 3.67B & $6.63 \mathrm{~A}$ & $6.49 \mathrm{~A}$ & & $2.06 \mathrm{~B}$ & $3.28 \mathrm{~A}$ & $3.32 \mathrm{~A}$ & \\
\hline & \multicolumn{8}{|c|}{ Second season: 2019} \\
\hline Pure sand (S) & $0.00 \mathrm{k}$ & $6.91 \mathrm{j}$ & $8.77 \mathrm{i}$ & $5.23 E$ & $0.00 \mathrm{k}$ & $2.21 \mathrm{j}$ & $3.03 \mathrm{i}$ & $1.75 \mathrm{E}$ \\
\hline $\mathrm{S}+\operatorname{clay}(3: 1, \mathrm{v} / \mathrm{v})$ & $9.82 \mathrm{~h}$ & $12.03 \mathrm{f}$ & $15.00 \mathrm{c}$ & $12.28 \mathrm{C}$ & $4.50 \mathrm{~g}$ & $6.02 \mathrm{ef}$ & $7.42 \mathrm{c}$ & $5.98 C$ \\
\hline $\mathrm{S}+$ clay $(1: 1, \mathrm{v} / \mathrm{v})$ & $10.95 \mathrm{~g}$ & $15.91 \mathrm{~b}$ & $12.93 \mathrm{e}$ & 13.27B & $4.99 \mathrm{~g}$ & $7.59 \mathrm{c}$ & $7.11 \mathrm{~cd}$ & $6.56 \mathrm{~B}$ \\
\hline S+ FYM compost $(3: 1, \mathrm{v} / \mathrm{v})$ & $11.47 \mathrm{fg}$ & $17.20 \mathrm{a}$ & $14.27 \mathrm{~d}$ & $14.31 \mathrm{~A}$ & $6.58 \mathrm{de}$ & $9.91 \mathrm{a}$ & $8.20 \mathrm{~b}$ & 8.23A \\
\hline S+ FYM compost $(1: 1, v / v)$ & $9.45 \mathrm{~h}$ & $11.20 \mathrm{~g}$ & $10.98 \mathrm{~g}$ & 10.54D & $3.72 \mathrm{~h}$ & $6.06 \mathrm{ef}$ & $5.64 \mathrm{f}$ & $5.14 D$ \\
\hline Mean & 8.34B & $12.65 \mathrm{~A}$ & $12.39 A$ & & $3.96 \mathrm{~B}$ & $6.36 \mathrm{~A}$ & $6.28 \mathrm{~A}$ & \\
\hline
\end{tabular}

* Means within a column or row having the same letters are not significantly different according to Duncan's New Multiple Range t-Test at $5 \%$ level.

Table (3): Effect of irrigation intervals, growing media and their interaction on roots fresh and dry weights of Ochna serrulata seedlings during 2018 and 2019 seasons

\begin{tabular}{|c|c|c|c|c|c|c|c|c|}
\hline \multirow[t]{3}{*}{ Irrigation interval ( day) } & \multicolumn{4}{|c|}{ Roots f. w. (g)/ plant } & \multicolumn{4}{|c|}{ Roots d. w. (g)/ plant } \\
\hline & 3 & 2 & 1 & Mean & 3 & 2 & 1 & Mean \\
\hline & \multicolumn{8}{|c|}{ First season: 2018} \\
\hline Pure sand (S) & $0.00 \mathrm{~h}$ & $1.15 \mathrm{~g}$ & $2.45 \mathrm{f}$ & $1.20 \mathrm{E}$ & $0.00 \mathrm{i}$ & $0.74 \mathrm{~h}$ & $1.02 \mathrm{gh}$ & $0.59 \mathrm{C}$ \\
\hline $\mathrm{S}+$ clay $(3: 1, \mathrm{v} / \mathrm{v})$ & $3.58 \mathrm{e}$ & $5.26 \mathrm{c}$ & $4.11 \mathrm{de}$ & $4.32 \mathrm{C}$ & $1.76 \mathrm{fg}$ & $3.22 \mathrm{a}-\mathrm{c}$ & $2.44 \mathrm{de}$ & 2.37B \\
\hline S + clay $(1: 1, \mathrm{v} / \mathrm{v})$ & $3.79 \mathrm{e}$ & $6.99 \mathrm{~b}$ & $3.96 \mathrm{e}$ & 4.91B & $3.26 \mathrm{a}-\mathrm{c}$ & $3.51 \mathrm{ab}$ & $2.29 \mathrm{de}$ & 3.02A \\
\hline S+ FYM compost $(3: 1, \mathrm{v} / \mathrm{v})$ & $4.83 \mathrm{~cd}$ & $8.06 \mathrm{a}$ & $5.13 \mathrm{c}$ & $6.01 \mathrm{~A}$ & $2.64 c-\mathrm{e}$ & $3.74 \mathrm{a}$ & $2.90 \mathrm{~b}-\mathrm{d}$ & 3.09A \\
\hline S+ FYM compost $(1: 1, \mathrm{v} / \mathrm{v})$ & $2.55 \mathrm{f}$ & $2.69 \mathrm{f}$ & $2.73 \mathrm{f}$ & $2.66 \mathrm{D}$ & $1.29 \mathrm{gh}$ & $2.79 \mathrm{~cd}$ & $1.98 \mathrm{ef}$ & $2.02 B$ \\
\hline \multirow[t]{2}{*}{ Mean } & $2.95 \mathrm{C}$ & 4.83A & $3.68 \mathrm{~B}$ & & $1.73 \mathrm{C}$ & $2.80 \mathrm{~A}$ & $2.13 B$ & - \\
\hline & \multicolumn{8}{|c|}{ Second season: 2019} \\
\hline Pure sand (S) & $0.00 \mathrm{~h}$ & $3.57 \mathrm{~g}$ & $4.46 \mathrm{f}$ & $2.68 \mathrm{E}$ & $0.00 \mathrm{~g}$ & $2.60 \mathrm{f}$ & $2.69 f$ & $1.76 \mathrm{E}$ \\
\hline $\mathrm{S}+\operatorname{clay}(3: 1, \mathrm{v} / \mathrm{v})$ & $5.88 \mathrm{e}$ & $8.94 \mathrm{c}$ & $7.73 \mathrm{~d}$ & $7.52 \mathrm{C}$ & $3.10 \mathrm{f}$ & $5.09 \mathrm{~cd}$ & $5.75 \mathrm{c}$ & $4.65 \mathrm{C}$ \\
\hline $\mathrm{S}+$ clay $(1: 1, \mathrm{v} / \mathrm{v})$ & $5.92 \mathrm{e}$ & $12.14 \mathrm{~b}$ & $7.33 \mathrm{~d}$ & $8.46 B$ & $3.97 \mathrm{e}$ & $8.01 \mathrm{~b}$ & $4.59 \mathrm{de}$ & $5.52 B$ \\
\hline S+ FYM compost $(3: 1, \mathrm{v} / \mathrm{v})$ & $8.73 \mathrm{c}$ & $18.16 \mathrm{a}$ & $11.75 \mathrm{~b}$ & $12.88 \mathrm{~A}$ & $4.17 \mathrm{e}$ & $10.27 \mathrm{a}$ & $7.70 \mathrm{~b}$ & $7.38 \mathrm{~A}$ \\
\hline S+ FYM compost $(1: 1, \mathrm{v} / \mathrm{v})$ & $4.68 \mathrm{f}$ & $7.30 \mathrm{~d}$ & $5.83 \mathrm{e}$ & 5.94D & $2.80 \mathrm{f}$ & $4.17 \mathrm{e}$ & $4.01 \mathrm{e}$ & 3.66D \\
\hline Mean & $5.04 \mathrm{C}$ & $10.02 \mathrm{~A}$ & $7.42 B$ & & $2.81 \mathrm{C}$ & $6.03 \mathrm{~A}$ & $4.95 B$ & \\
\hline
\end{tabular}

* Means within a column or row having the same letters are not significantly different according to Duncan's New Multiple Range t-Test at $5 \%$ level. 
vital processes in plant tissues and producing more metabolites that stimulate growth (Gonzalez and Cooperband, 2003). These findings, coincide with those obtained by Saadawy et al. (2005) on Schefflera actinophylla, Henson et al. (2006) on Catharanthus roseus, Rudbeckia hirta, Senecio cineraria, Tagetes erecta and Petunia hybrida, Ibrahim et al. (2010) on Helichrysum bracteatum, El-Quasni et al. (2014) on Magnolia grandiflora, Sarhan et al. (2016 b) on Moringa oleifera. In this connection, Moore and Broschat (2001) revealed that Pentas lanceolat, Crossandra infundibuliformis and Philodendron " Hope" plants grown in Pro-mix GSX medium and sub irrigated daily were largest, while that was true for areca palm plants that were grown in either Metro-mix 500 or $60 \%$ biosolid media and watered overhead daily. Elongating irrigation interval to 3 days gave the least shoot dry weight in the four studied plants regardless of the medium used.

Likewise, Mazher et al. (2012) reported that applying $200 \mathrm{~g}$ Nile compost/pot and irrigating every 2 days greatly improved growth and flowering of Amaranthus tricolor plant than adding $100 \mathrm{~g} / \mathrm{pot}$ and prolonging water interval up to 4 or 6 days. On Hymenocallis speciosa, Nofal et al. (2014) advised to use sand/ compost $(2: 1, \mathrm{v} / \mathrm{v})$ mixture for planting and the moderate level for irrigation every 3 days for best growth and quality. Akhtar (2019) suggested that watering Calendula officinalis and Dianthus barbatus plants at 4 days interval recorded maximum values of plant height, stem diameter, root length, shoot fresh and dry weights, root dry weight, No. flower buds, No. opened flowers and flower diameter than irrigating daily or every 2 days. Do Bomfim et al. (2020) found that, for Ananas comosus var. Erectifolius, the irrigation interval at 2 days highly improved the plant height, No. leaves, leaf length, rosette diameter and flowering rate than the irrigation intervals between 4 to 10 days.

\subsubsection{Chemical composition of the leaves}

An identical response to that of vegetative and root growth parameters was also observed regarding the concentrations of chlorophyll $a, b$ and carotenoids (mg/g f. w.), and total soluble sugars (\%) in the leaves (Tables, 4 and 5), where the values of these constituents reached maximum in the leaves of plants grown in sand + FYM compost (3:1, v/v), medium with significant differences relative to the other media in both seasons. Also, irrigation interval at 2 days gave the highest records in the two seasons, as compared with 3 and 1 day intervals which gave lower scores. So, the greatest means of the abovementioned constituents were achieved by interacting between planting in sand + FYM compost $(3: 1, \mathrm{v} / \mathrm{v})$ medium and watering at two days interval, as such combination got the utmost high concentrations of pigments and soluble sugars in the leaves over the other combinations in both seasons. This may be due to the synergistic effect of both the proper water interval and the favorable composted medium on supplying Ochna serrulata plants with their required water and nutrients necessary for accelerating metabolism processes, which increased the concentrations of the active constituents in plant tissues.

The previous results can be supported by those gained by Saadawy et al. (2005) on Peperomia, Schefflera and Syngonium, AbdelFattah et al. (2008) on Schefflera actinophylla, El-Sayed et al. (2013) on Euonymus japonicus cv. Aureus, Mohamed et al. (2014) on Curcuma aromatica and $C$. domestica, Abdel-Moneim et al. (2018) on Euphorbia milii and El-Leithy et al. (2018) on rosemary plants. In this concern, Saadawy et al. (2011) clarified that growth performance of Ficus nitida "Hawaii" plants was the best when the plants were grown in peat moss + water hyacinth compost + rice hulls compost + date palm leaf compost (at equal volume parts) mixture and irrigating with $450 \mathrm{ml}$ of water/ pot/ week, and as such combination treatment increased the concentrations of total chlorophylls, carotenoids, total soluble sugars, $\mathrm{N}, \mathrm{P}$ and $\mathrm{K}$ to highest means compared to other combinations, even when water supply raised to $600 \mathrm{ml} /$ pot /week. On Amaranthus tricolor plant, Mazher et al. (2012) reported that the highest concentrations of total chlorophyll, carotenoids, total carbohydrates, N, P and $\mathrm{K}$ were attained by planting in sand amended with $200 \mathrm{~g}$ Nile compost/ pot and irrigating once every 2 days. Similarly, Said (2016) pointed out that combining between planting the variegated duranta transplants in sand fortified with poultry manure compost $(2: 1, \mathrm{v} / \mathrm{v})$ and irrigating with $300 \mathrm{ml}$ water/ pot, at 2 days interval markedly improved the contents total chlorophyll, carotenoids, total carbohydrates, N, P and $\mathrm{K}$ in the leaves compared to the other combined treatments.

From the foregoing data, it is prefer to culture Ochna serrulata plants under shade in a mixture of sand + FYM compost $(3: 1, \mathrm{v} / \mathrm{v})$ and 
Table (4): Effect of irrigation intervals, growing media and their interaction on pigments concentrations in Ochna serrulata leaves during 2018 and 2019 seasons.

\begin{tabular}{|c|c|c|c|c|c|c|c|c|c|c|c|c|}
\hline \multirow[t]{2}{*}{ Irrigation Interval ( day) } & \multicolumn{4}{|c|}{ Chlorophyll a (mg/g f. w.) } & \multicolumn{4}{|c|}{ Chlorophyll b (mg/g f. w.) } & \multicolumn{4}{|c|}{ Carotenoids (mg/g f. w.) } \\
\hline & 3 & 2 & 1 & Mean & 3 & 2 & 1 & Mean & 3 & 2 & 1 & Mean \\
\hline & \multicolumn{12}{|c|}{ First season: 2018} \\
\hline Pure sand (S) & $0.000 \mathrm{~h}$ & $0.353 \mathrm{~g}$ & $0.371 \mathrm{~g}$ & $0.241 \mathrm{D}$ & $0.000 \mathrm{i}$ & $0.093 \mathrm{~h}$ & $0.111 \mathrm{gh}$ & $0.068 E$ & $0.000 \mathrm{i}$ & $0.200 \mathrm{~h}$ & $0.213 \mathrm{~h}$ & $0.138 D$ \\
\hline $\mathrm{S}+$ clay $(3: 1, \mathrm{v} / \mathrm{v})$ & $0.409 \mathrm{~g}$ & $0.891 \mathrm{c}$ & $1.114 \mathrm{~b}$ & $0.805 B$ & $0.128 \mathrm{fg}$ & $0.271 \mathrm{~d}$ & $0.313 \mathrm{c}$ & $0.237 \mathrm{C}$ & $0.240 \mathrm{~h}$ & $0.455 \mathrm{~d}$ & $0.472 \mathrm{~cd}$ & $0.389 B$ \\
\hline S + clay $(1: 1, \mathrm{v} / \mathrm{v})$ & $0.448 \mathrm{fg}$ & $1.125 \mathrm{~b}$ & $0.915 \mathrm{c}$ & $0.829 \mathrm{~B}$ & $0.150 \mathrm{f}$ & $0.402 \mathrm{a}$ & $0.301 \mathrm{c}$ & $0.284 B$ & $0.246 \mathrm{gh}$ & $0.571 \mathrm{~b}$ & $0.459 \mathrm{~cd}$ & $0.425 B$ \\
\hline S+ FYM compost $(3: 1, \mathrm{v} / \mathrm{v})$ & $0.532 \mathrm{ef}$ & $1.595 \mathrm{a}$ & $0.936 \mathrm{c}$ & $1.021 \mathrm{~A}$ & $0.219 \mathrm{e}$ & $0.413 \mathrm{a}$ & $0.360 \mathrm{~b}$ & $0.331 \mathrm{~A}$ & $0.308 \mathrm{fg}$ & $0.683 a$ & $0.524 \mathrm{bc}$ & $0.505 \mathrm{~A}$ \\
\hline S+ FYM compost $(1: 1, \mathrm{v} / \mathrm{v})$ & $0.406 \mathrm{~g}$ & $0.742 \mathrm{~d}$ & $0.548 \mathrm{e}$ & $0.565 \mathrm{C}$ & $0.123 \mathrm{~g}$ & $0.270 \mathrm{~d}$ & $0.274 \mathrm{~d}$ & $0.222 \mathrm{D}$ & $0.222 \mathrm{~h}$ & $0.414 \mathrm{de}$ & $0.367 \mathrm{ef}$ & $0.334 \mathrm{C}$ \\
\hline \multirow[t]{2}{*}{ Mean } & $0.359 \mathrm{C}$ & $0.941 \mathrm{~A}$ & $0.777 \mathrm{~B}$ & & $0.124 \mathrm{C}$ & $0.290 \mathrm{~A}$ & $0.272 \mathrm{~B}$ & & $0.203 \mathrm{C}$ & $0.465 A$ & $0.407 B$ & \\
\hline & \multicolumn{12}{|c|}{ Second season: 2019} \\
\hline Pure sand (S) & $0.000 \mathrm{j}$ & $0.375 \mathrm{i}$ & $0.393 \mathrm{hi}$ & $0.256 \mathrm{E}$ & 0.0001 & $0.109 \mathrm{k}$ & $0.126 \mathrm{j}$ & $0.078 E$ & $0.000 \mathrm{i}$ & $0.205 \mathrm{~h}$ & $0.219 \mathrm{~h}$ & $0.141 \mathrm{E}$ \\
\hline $\mathrm{S}+$ clay $(3: 1, \mathrm{v} / \mathrm{v})$ & $0.437 \mathrm{hi}$ & $0.907 \mathrm{de}$ & $0.960 \mathrm{~d}$ & $0.768 \mathrm{C}$ & $0.146 \mathrm{i}$ & $0.296 \mathrm{f}$ & $0.319 \mathrm{e}$ & $0.254 \mathrm{C}$ & $0.259 \mathrm{gh}$ & $0.462 \mathrm{~cd}$ & $0.511 \mathrm{c}$ & $0.410 \mathrm{C}$ \\
\hline $\mathrm{S}+$ clay $(1: 1, \mathrm{v} / \mathrm{v})$ & $0.460 \mathrm{~h}$ & $1.155 \mathrm{c}$ & $0.936 \mathrm{de}$ & $0.850 \mathrm{~B}$ & $0.165 \mathrm{~h}$ & $0.423 b$ & $0.345 \mathrm{~d}$ & $0.311 B$ & $0.283 \mathrm{fg}$ & $0.575 \mathrm{~b}$ & $0.486 \mathrm{~cd}$ & $0.448 B$ \\
\hline S+ FYM compost $(3: 1, \mathrm{v} / \mathrm{v})$ & $0.567 \mathrm{~g}$ & $1.710 \mathrm{a}$ & $1.231 \mathrm{~b}$ & $1.170 \mathrm{~A}$ & $0.233 \mathrm{~g}$ & $0.584 \mathrm{a}$ & $0.380 \mathrm{c}$ & $0.399 \mathrm{~A}$ & $0.322 \mathrm{ef}$ & $0.724 \mathrm{a}$ & $0.568 \mathrm{~b}$ & $0.538 \mathrm{~A}$ \\
\hline S+ FYM compost $(1: 1, \mathrm{v} / \mathrm{v})$ & $0.420 \mathrm{hi}$ & $0.866 \mathrm{e}$ & $0.657 \mathrm{f}$ & $0.647 \mathrm{D}$ & $0.143 \mathrm{i}$ & $0.285 \mathrm{f}$ & $0.228 \mathrm{~g}$ & $0.219 \mathrm{D}$ & $0.249 \mathrm{gh}$ & $0.444 \mathrm{~d}$ & $0.378 \mathrm{e}$ & $0.357 \mathrm{D}$ \\
\hline Mean & $0.377 \mathrm{C}$ & $1.003 \mathrm{~A}$ & $0.835 B$ & & $0.137 \mathrm{C}$ & $0.339 \mathrm{~A}$ & $0.280 \mathrm{~B}$ & & $0.223 \mathrm{C}$ & $0.482 \mathrm{~A}$ & $0.432 B$ & \\
\hline
\end{tabular}

* Means within a column or row having the same letters are not significantly different according to Duncan's New Multiple Range t-Test at $5 \%$ level.

Table (5): Effect of irrigation intervals, growing media and their interaction on total soluble sugars concentrations in Ochna serrulata leaves during 2018 and 2019 seasons.

\begin{tabular}{|c|c|c|c|c|}
\hline \multirow[t]{2}{*}{ Irrigation interval ( day) } & \multicolumn{4}{|c|}{ Total soluble sugars (\%) } \\
\hline & 3 & 2 & 1 & Mean \\
\hline & \multicolumn{4}{|c|}{ First season: 2018} \\
\hline Pure sand (S) & $0.000 \mathrm{k}$ & $1.663 \mathrm{j}$ & $1.853 \mathrm{i}$ & $1.172 \mathrm{E}$ \\
\hline S + Clay (3:1) & $3.020 \mathrm{gh}$ & $3.207 \mathrm{f}$ & $3.373 \mathrm{e}$ & $3.200 \mathrm{C}$ \\
\hline S + Clay (1:1) & $3.190 \mathrm{f}$ & $4.257 \mathrm{~b}$ & $3.330 \mathrm{e}$ & 3.592B \\
\hline S+ FYM compost $(3: 1)$ & $3.483 d$ & $4.590 \mathrm{a}$ & $3.653 c$ & $3.909 \mathrm{~A}$ \\
\hline S+ FYM compost $(1: 1)$ & $2.947 \mathrm{~h}$ & $3.163 \mathrm{f}$ & $3.123 \mathrm{fg}$ & 3.078D \\
\hline \multirow[t]{2}{*}{ Mean } & $2.528 \mathrm{C}$ & $3.376 \mathrm{~A}$ & 3.067B & \\
\hline & \multicolumn{4}{|c|}{ Second season: 2019} \\
\hline \begin{tabular}{|l|} 
Pure sand (S) \\
\end{tabular} & $0.000 \mathrm{j}$ & $2.293 \mathrm{i}$ & $2.467 \mathrm{~h}$ & $1.587 \mathrm{E}$ \\
\hline S + Clay $(3: 1, \mathrm{v} / \mathrm{v})$ & $3.930 \mathrm{e}$ & $4.053 \mathrm{de}$ & $4.657 \mathrm{~b}$ & $4.213 \mathrm{C}$ \\
\hline $\mathrm{S}+$ Clay $(1: 1, \mathrm{v} / \mathrm{v})$ & $4.003 \mathrm{e}$ & $5.687 \mathrm{a}$ & $4.180 \mathrm{~d}$ & 4.623B \\
\hline S+ FYM compost $(3: 1, \mathrm{v} / \mathrm{v})$ & $4.793 b$ & $5.717 \mathrm{a}$ & $4.480 \mathrm{~d}$ & 4.997A \\
\hline S+ FYM compost $(1: 1, \mathrm{v} / \mathrm{v})$ & $3.273 \mathrm{~g}$ & $3.617 \mathrm{f}$ & $3.710 \mathrm{f}$ & 3.533D \\
\hline Mean & $3.200 \mathrm{C}$ & $4.273 \mathrm{~A}$ & 3.899B & \\
\hline
\end{tabular}

*Means within a column or row having the same letters are not significantly different according to Duncan's New Multiple Range t-Test at $5 \%$ level.

irrigating them once every 2 days to accelerate growth of this slow- growing shrub during the incubation period in the nursery for quick marketing.

\section{REFERENCES}

Abdel-Fattah G. H., El-Fouly A.S. and RezkAllah B.B. (2008). Effect of different growing mixtures on growth and chemical composition of Brassaia plant. Ann. Agric., Moshtohor, 46(4): 477-482.

Abdel-Moneim A.M., Abdul-Moneem N.E. and Ibrahim A.K. (2018). The effect of watering regimes and bio- and chemical treatments on flowering of Euphorbia milii var. longifolia plants. Sci. J. Flowers Ornament. Plants, 5(4): 323346.

Ahmad N., Ahmad M., Ullah I. and AbdulBasit A. (2020). Effect of irrigation intervals on growth and production of roselle (Hibiscuss sabdariffa). Biosci. Res., 17(2): 759-767.

Akhtar G. (2019). Effect of irrigation intervals on growth of annual flowers under climatic conditions of South Punjab, Pakistan. Appl. Biol., (PAB), 8(4): 21692177. 
Bandi A.K., Lee D.U., Tih R.G., Gunasekar D. and Bodo B. (2012). Phytochemical and biological studies of Ochna species. Chem. Biodivers., 9(2):251-271.

Do Bomfim G.V., Santos M. D., De Azevedo B.M., De Carvalho Ana Christina P.P. and Fernandes C.N. (2020). Usage irrigation intervals in the production of ornamental pineapple in pots. Revista Caatinga, 33(1): 226-235.

Drechsel P. and Reck B. (1998). Composted shrub-pruning and other organic manures for smallholder farming systems in southern Rwanda. Agroforestry Systems, 39(1): 1-12.

Dubois M., Smith F., Illes K.A., Hamilton J. K. and Rebers P.A. (1956). Colorimetric method for determination of sugars and related substances. Ann. Chem., 28(3): 350-356.

El-Leithy A.S., Hanafy M.S. and Anaam G.A. (2018). Effect of irrigation intervals, CytoFlow Amin-50 and their interaction on rosemary (Rosmarinus officinalis L.). II- On chemical constituents. Middle East J. Agric. Res., 7(3): 768-781.

El-Mekawy M.A.M. (2013). Response of Achillea santolina L. to fertilizers under different irrigation intervals. Asian J. Crop Sci., 5: 338-359.

El-Quasni F.E., Mazhar A.M., Sakr Salwa S., El-Khateeb M.A. and Abdel-Magied H.A. (2014). Effect of some growing media on growth and chemical constituents of Magnolia seedlings (Magnolia grandiflora L.). Middle East J. Agric. Res., 3(4): 869-875.

El-Sayed B.A., El-Fouly A.S. and Shahin S.M. (2013). Response of spindle tree (Euonymus japonicus $\mathrm{cv}$. aureus) plant to some growing media. J. Bio. Chem. Environ. Sci., 8(3): 61-71.

Fidelis Q.C., Ribeiro Tereza A. N. , Araujo M.F. and de Carvalho M.G. (2014). Ochna genus: chemical and pharmacological aspects. Rev. Bras. Farmacogn, 24(1): 10-15.

Gonzalez R.F. and Cooperband L.R. (2003). Compost effects on soil chemical properties and field nursery production. J. Environ. Hort., 21(1): 38-44.

Hattatt L. (2001). Encyclopedia of Garden Plants and Flowers. Parragon Queen Streen House, Bath, BAIIHE, UK., pp. 256.
Henson D.Y., Newman S.E. and Hartley D.E. (2006). Performance of selected herbaceous annual ornamentals grown at decreasing levels of irrigation. Hort. Sci., 41(6): 1481-1486.

Huxley A., Griffiths M. and Levy M. (1992). The New Royal Hort. Soci. dictionary of gardening. The Stockton Press, New York, N.Y. 10010, USA. vol.3, pp. 790.

Ibrahim S.M., Taha L.S. and Farahat M.M. (2010). Influence of foliar application of peptone on growth, flowering and chemical composition of Helichrysum bracteatum plants under different irrigation intervals. Ozean J. Appl. Sci., 3(1): 143-155.

Makhafola T.J. and Eloff J.N. (2012): Five Ochna species have high antibacterial activity and more than ten antibacterial compounds. South African J. Sci., 108 (1/2): 1-6.

Mazher A.A., Mahgoub M.H., Abdel-Raheem Kh.M. and Zaghloul S.M. (2012). Influence of Nile compost application on growth, flowering and chemical composition of Amaranthus tricolor under different irrigation intervals. Middle East J. Sci. Res., 12(6): 751-759.

Mead R., Curnow R.N. and Harted A.M. (1993). Statistical Methods in Agriculture and Experimental Biology. $2^{\text {nd }}$ Ed., Chapman \& Hall Ltd., London, UK, pp. 335.

Meshaal M.S., Emam K.A., Ghareb Fawzia Z. and Khella Evon A. (2018). Economical study of in vivo and in vitro propagation of Russelia equisetiformis. Sci. J.

Flowers Ornament. Plants, 5(1): 67-87.

Mohamed M.A., Wahba H.E., Ibrahim M.E. and Yousef A.A. (2014). Effect of irrigation intervals on growth and chemical composition of some Curcuma spp. plants. Nusanrara Biosci., 6(2): 140-145.

Moore K.K. and Broschat T.K. (2001). Effect of four growing substrates on growth of ornamental plants in two irrigation systems. HortTechnol., 11(3): 456-460.

Nofal E.M.S., El-Tarawy M. and Nabih A. (2014). Quantifying the most suitable irrigation regime for Hymenocallis speciosa Salisb plant grown in different potting media under open nursery condition. Sci. J. Flowers \& Ornament. Plants, 1(3): 199-221.

Saadawy F.M., Rezk-Alla B.B. and El-Fouly Amal S. (2005). Production of some indoor plants 
using natural local media. J. Agric. Sci., Mansoura Univ., 30 (12): 8013-8035.

Saadawy F.M., Rezk-Alla B.B. and El-Fouly Amal S. (2011). Natural local media and their effect on water requirements of Ficus "Hawaii". J. Plant Product., Mansoura Univ., 2 (2): 239263.

Said R.M. (2016). Response of sky flower (Duranta erecta L. var. variegata) transplants as potplant to growing media and water amounts. Middle East J. Sci. Res., 5(2): 201-207.

Sarhan A.M. Arafa A.M. S. and Gonaw H.A. (2016). Response of Moringa oleifera trees to biochemical fertilization and growing media. Sci. J. Flowers Ornament. Plants, 3(4): 255263.

Shahin S.M., Mahmoud A.M. A. and Abdalla M. Y. A. (2007). Response of Agave americana L. cv. Marginata to different growing media and water quantities. J. Agric. Sci., Mansoura Univ., 32(11): 9227-9240.

Shahin S.M., Mahmoud A.M.A. and Abdalla M.Y.A. (2009). A study to determine fertilization rate and water quantity suitable for growth and quality of tuberose plants cultivated in some soil types. J. Agric. Sci., Mansoura Univ., 34(4): 3713-3731.

Silva F.A.S. and Azevedo C.A.V. (2016). The Assistant Software, ver. 7.7 and its use in the Analysis of Experimental Data. Afr. J. Agric. Res., 11(39): 3733-3740.

Steel R.G.D. and Torrie J.H. (1980). Principles and Procedures of Statistics. McGrow Hill Book Co. Inc., New York, USA., pp. 377- 400.

Sumanta N., Haque C.I., Nishika J. and Suprakash R. (2014). Spectrophotometric analysis of chlorophyllous and carotenoids from commonly grown Fern sp. by using various extracting solvents. Res. J. Chem. Sci., 4(9): 63- 69.

Tahir M., Ali A. and Nadeem M. (2007). Performance of canola (Brassica napus L.) under different irrigation levels. Pak. J. Bot., 39(3): 739-746.

Voegele E. (2013). Australian study assesses biodiesel feedstocks. National Advanced Biofuels Conf. \& Expo. Sept. 10-12, BBI International, Omaha, Nebraska, USA.

$$
\begin{aligned}
& \text { دراسات فسيولوجية على إنباتثت ونمو شجيرة الأوكنا }
\end{aligned}
$$

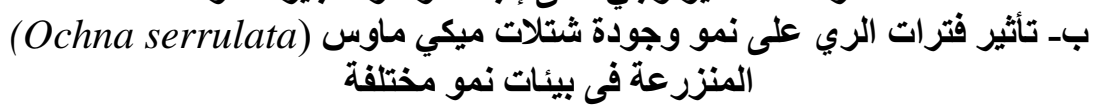

$$
\begin{aligned}
& \text { * سيد محمد شاهين - أحمد وهبة سيد }
\end{aligned}
$$

قسم بحوث الحدائق النباتية و * قسم بحوث الزينة وتتسيق الحدائق، مركز البحوث الزر اعية، الجيزة، مصر.

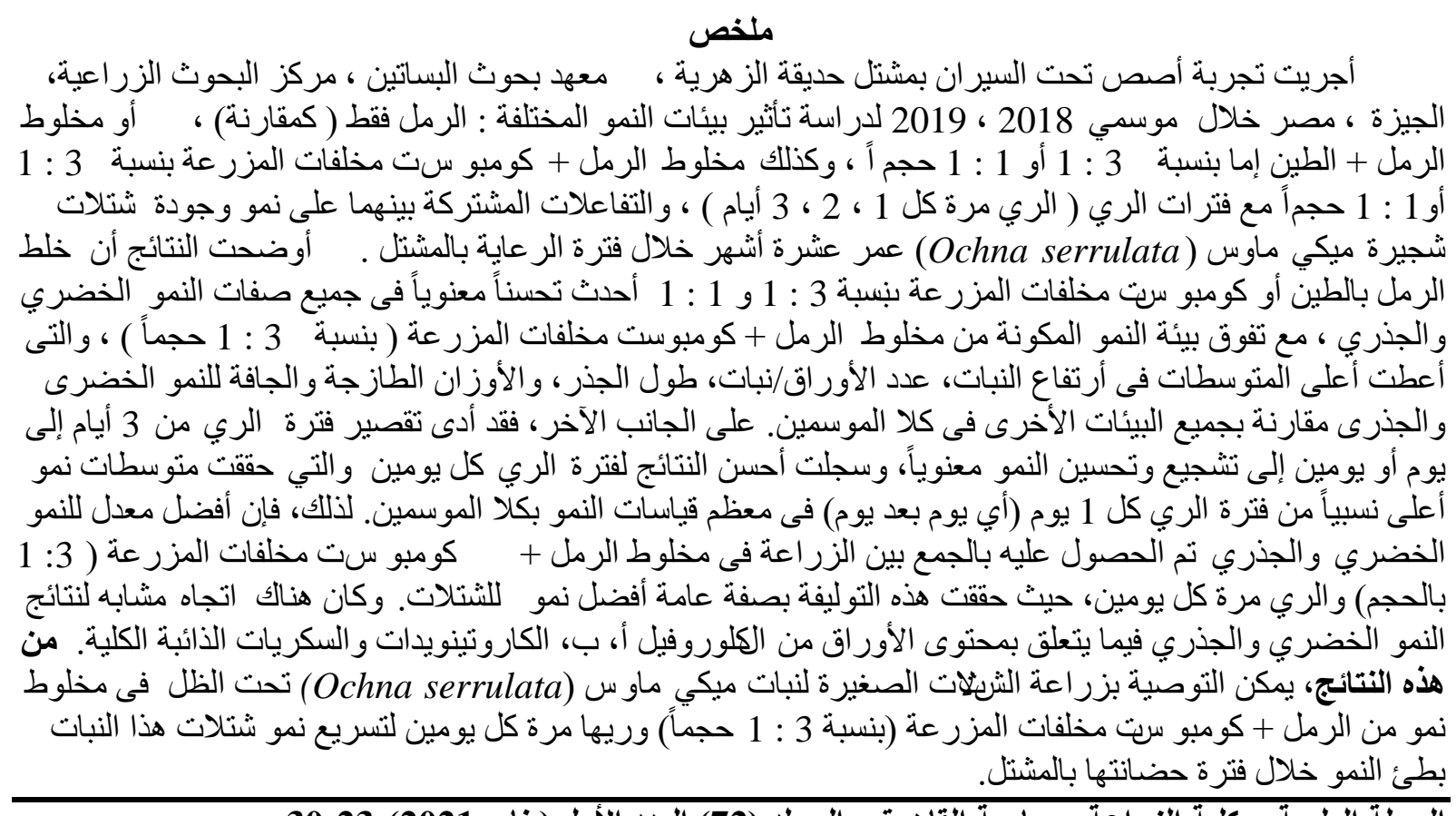

